\title{
Strategi Bisnis E-Commerce Dalam Optimalisasi \\ Tingkat Hunian Kamar Hotel Dan Villa
}

\author{
by \\ Ida Bagus Fajar Eka Putra ${ }^{(1)}$ \\ Ida Bagus Teddy Prianthara ${ }^{(2)}$ \\ Dinas Penanaman Modal \& PST Kab. Klungkung ${ }^{(1)}$ \\ Universitas Pendidikan Nasional (2) \\ idabagusfajar@gmail.com ${ }^{(1)}$ \\ gusteddy@undiknas.ac.id ${ }^{(2)}$
}

\begin{abstract}
Conventional market transformation into a digital market is influenced by the development of E-commerce technology. Conventional marketing previously used as a marketing media has diminished with the presence of E-commerce technology, conventional market considered to have a shortage in terms of high costs and narrow market reach. The presence of E-commerce is able to expand the market with internet media as a distribution of information to prospective customers. The results of this study found Avilla Group to deal with competitors. Avilla Group using offline and Online market mix techniques in the process of marketing rooms. The offline market is still maintained for maintenance purposes for some customers who have more trust in offline travel agents. The average occupancy rate of units consists of 40\% offline and 60\% online. E-commerce marketing on Avilla Group is supported by 2 main systems, which are internal system and the Channel manager. The results of SWOT analysts obtain system development innovation instruments to face competitors can be developed on internal systems, so that the strength and opportunities of the online market can be maximized which has an impact on optimal room occupancy rates.
\end{abstract}

Keywords: E-commerce, Occupancy

\section{ABSTRAK}

Transformasi pasar konvensional mejadi pasar digital dipengaruhi oleh perkembangan teknologi E-commerce. Pemasaran konvensional yang digunakan sebelumnya sebagai media pemasaran semakin berkurang dengan hadirnya teknologi E-commerce, konvensional dinilai memiliki kekurangan dari sisi biaya yang tinggi dan jangkauan pasar yang sempit. Kehadiran E-commerce mampu memperluas pasar dengan media internet sebagai pendistribusian informasi ke calon kastemer.Hasil penelitian ini menemukan Avilla Group unuk menghadapi pesaing. Avilla Group menggunakan teknik market mix offline dan Online dalam prosses pemasaran kamar. Pasar offline masih dipertahankan bertujuan untuk maintenance sebagian kastemer yang memiliki kepercayaan lebih pada offline travel agent. Tingkat hunian rata - rata unit terdiri dari $40 \%$ offline dan $60 \%$ online. Pemasaran dengan E-commerce pada Avilla Group didukung dengan 2 sistem utama, yaitu sistem internal dan Channel manager. Hasil SWOT analis memperoleh instrument inovasi pengembangan sistem untuk menghadapi pesaing dapat dikembangkan pada sistem internal, sehingga kekuatan dan peluang pasar online dapat dimaksimalkan yang berdampak pada tingkat hunian kamar yang optimal.

\section{Kata kunci : E-commerce, Occupancy}




\section{PENDAHULUAN}

Secara geografis pulau Bali berbatasan dengan laut Bali di bagian utara, provinsi Nusa Tenggara Barat di bagian timur, Samudera Hindia di bagian selatan dan pulau Jawa di bagian barat. Bali terdiri dari dua Pulau yaitu Nusa Penida dan Bali daratan. Budaya Bali sangat dipengaruhi oleh budaya India, Cina, dan khususnya Hindu (Darma, 2019). Bali dikenal sebagai destinasi wisata yang menawarkan sebuah keunikan budaya khas Bali mulai dari keunikan arsitektur bangunan rumah, musik gambelan dan kekayaan seni tari. Mayoritas penduduk Bali menganut agama Hindu sehingga Bali juga dikenal dengan pulau seribu Pura, keindahan alam yang dimiliki Bali yang dipadukan budaya khas daerah seolah menjadi magnet alami untuk menarik wisatawan untuk berkunjung ke Bali. Menurut laporan Badan Pusat Statistik Provinsi Bali Tahun 2017 mencatat 10 Negara wisatawan yang memberi kontribusi terbesar bagi pariwisata Bali, yaitu : Tiongkok (109.534), Australia (93.991), India (22.449), Inggris (21.466), Jerman (19.460), Jepang (19.444), Perancis (18.423), Korea Selatan (13.416), Amerika Serikat (1.324), dan Malaysia (11.892) wisatawan. Tingginya kunjungan wisatawan mempengaruhi kebutuhan fasilitas penginapan sebagai pendukung perkembangan pariwisata, mengingat kunjungan wisatawan yang datang dari berbagai negara yang memerlukan tempat untuk beristirahat. Berbagai Fasilitas akomodasi penginapan disediakan sebagai pendukung pariwisata, seperti hotel dan villa, peranan penginapan dalam industri pariwisata diatur juga dalam UUD NO. 10 Tahun 2009 dimana setiap daerah yang memiliki potensi pariwisata dapat dibina dengan baik dan berbagai macam kegiatan wisata dan didukung berbagai fasilitas serta layanan yang disediakan oleh masyarakat, pengusaha, dan pemerintah daerah.

Kehadiran teknologi informasi sebagai alat bantu pemasaran sangat menentukan keberhasilan pemasaran jasa penginapan di era digital (Darma, 2018). Pemasaran berbasis digital atau $E$-commerce memanfaatkan internet sebagai media pendistribusian informasi. $E$ commerce adalah sistem yang dibangun untuk media promosi memperkenalkan barang atau jasa kepada calon customer melalui sistem elektronik (Handika dkk, 2018; Darma dkk, 2019). Menurut Jony Wong (2010) pengertian dari E-commerce adalah pembelian, penjualan dan pemasaran barang serta jasa melalui sistem elektronik. Seperti radio, televisi dan jaringan komputer atau internet. Internet adalah media sejuta umat yang dapat diakses tanpa batasan waktu, internet menawarkan kecepatan, efisiensi untuk bertukar informasi tanpa harus ketempat tujuan. Menurut Strauss dan Frost (2013) dan Pranata dan Darma (2014) mendefinisikan Internet adalah jaringan global yang meliputi jutaan perusahaan, pemerintah, organisasi dan jaringan pribadi. sebagai media pemasaran yang terdiri dari jaringan komputer 
diseluruh dunia yang menghubungkan ratusan ribu jaringan yang saling bertukar data. Penelitian sebelumnya oleh Rian Piarna dengan metode kuantitatif menganalisis pengaruh sumber informasi dan kualitas website terhadap kepercayaan dan keputusan pelanggan untuk bertransaksi pada E-commerce. Sampel penelitian sebanyak 150 pelanggan E-commerce di Indonesia. Pengumpulan data menggunakan kuesioner online dan dianalisis dengan Structural Equation Model (SEM). Hasilnya menunjukkan sumber informasi secara langsung tidak mempengaruhi kepercayaan dan keputusan bertransaksi. Sedangkan, kualitas website memiliki pengaruh signifikan terhadap kepercayaan pelanggan E-commerce namun tidak berpengaruh langsung terhadap keputusan bertransaksi.

Kondisi saat ini yang dihadapi oleh perusahaan yang bergerak pada penyedia jasa penginapan adalah bagaimana merubah strategi pemasaran offline mengarah ke pemasaran online untuk mengoptimalkan tingkat hunian kamar (Kusnadi dan Darma, 2018). Pertumbuhan pariwisata menciptakan pesaing baru dibidang jasa penginapan sekaligus menjadi ancaman bagi kelangsungan bisnis perusahaan, berdasarkan data Badan Pusat Statistik Provinsi Bali tahun 2016 pembangunan hotel berdasarkan klasifikasi bintang, yang pertama hotel dengan bintang 2 dengan jumlah 22 unit dengan total jumlah kamar 1.241, Selanjutnya bintang 3 dengan jumlah 49 unit dengan total kamar 3.997, bintang 4 dengan jumlah 75 unit dengan jumlah kamar 10.732 dan yang berbintang 5 dengan total kamar 15.081. Salah satu management hotel yaitu Avilla yang terletak dikabupaten Badung merupakan salah satu perusahaan yang bergerak dalam industri penginapan. Avilla menunjukan data dari $100 \%$ tingkat hunian kamar, $40 \%$ menggunakan pasar offline dan $60 \%$ menggunakan pasar Online. Angka ini menunjukan bahwa unit masih mengunakan pasar offline untuk menarik calon customer, pasar offline memiliki kekurangan dari segi biaya yang tinggi, jangkauan pasar yang sempit dan efektitas waktu kurang. Dalam penelitian ini peneliti berharap dapat membantu melihat peluang pemasaran E-commerce dengan memperhatikan ancaman dari banyaknya pesaing, memaksimalkan keunggulan management dan membangun inovasi baru untuk memperoleh tingkat hunian yang diharapkan. 


\section{TELAAH PUSTAKA}

\section{Kajian Teori Pendukung Penelitian}

\section{Teori E-Commerce}

Pengertian dari E-commerce adalah pembelian, penjualan dan pemasaran barang serta jasa melalui sistem elektronik. Seperti radio, televisi dan jaringan komputer atau internet. Jadi pengertian E-commerce adalah proses transaksi jual beli yang dilakukan melalui internet dimana website digunakan sebagai wadah untuk melakukan proses tersebut (Jony Wong, 2010; Dewi dan Darma, 2014; Pranata dan Darma, 2014).

\section{Teori WEB}

Menurut Widya (2016); Ferdiana dan Darma (2019), Website (WWW) adalah sebuah aplikasi yang berjalan di internet. Menyatakan bahwa: World Wide Web yakni sebuah sistem dimana informasi dalam bentuk teks, gambar, suara, dan lain-lain dipresentasikan dalam bentuk Hypertext dan dapat diakses oleh perangkat lunak yang disebut browser. Informasi di web pada umumnya di tulis dalam format HTML.

\section{Teori Pemasaran Jasa}

Pemasaran merupakan salah satu kegiatan-kegiatan pokok yang dilakukan dalam usaha untuk mempertahankan kelangsungan hidup untuk berkembang, dan mendapatkan laba. Inti dari pemasaran adalah memuaskan kebutuhan dan keinginan konsumen. Sasaran dari bisnis adalah mengantarkan nilai pelanggan untuk menghasilkan laba. Untuk penciptaan dan menghantarkan nilai dapat meliputi fase memilih nilai, fase menyediakan nilai, dan fase mengkomunikasikan nilai (Maharani dan Darma, 2018; Kotler dan Keller, 2009; Kanten dan Darma, 2017; Adnyana dan Darma, 2015).

\section{Analisis SWOT}

Analisis SWOT menurut Philip Kotler (2009) diartikan sebagai evaluasi terhadap keseluruhan kekuatan, kelemhan, peluang dan ancaman. Sedangkan menurut Freddy Rangkuti (2013), analisis SWOT diartikan sebagai: “Analisa yang didasarkan pada logika yang dapat memaksimalkan kekuatan (strengths) dan peluang (opportunities), namun secara bersamaan dapat meminimalkan kelemahan (weaknesses) dan ancaman (threats)".

\section{Penelitian Terdahulu}

1. Rian Piarna, penelitiannya yang menganalisa Pengaruh Sumber Informasi dan Kualitas Website terhadap Kepercayaan Pelanggan dalam Menentukan Keputusan 
Bertransaksi pada E-commerce (2011); Ferdiana \& Darma (2019). Hasilnya menunjukkan sumber informasi secara langsung tidak mempengaruhi kepercayaan dan keputusan bertransaksi. Sedangkan, kualitas website memiliki pengaruh signifikan terhadap kepercayaan pelanggan E-commerce namun tidak berpengaruh langsung terhadap keputusan bertransaksi.

2. Yuniar, penelitiannya yang menganalisa Pengaruh Empati, Persuasi, Dampak, Komunikasi Terhadap Citra Merek Dikalangan Mahasiswa Program Pasca Sarjana Magister Manajemen Universitas Syiah Kuala Banda Aceh. Penelitian Yuniar menggunakan metode kuantitatif, hasil dari penelitiannya memaparkan bahwa pengaruh empati, dampak persuasi, dan komunikasi pada citra merek dan untuk mengidentifikasi merek Aqua di iklan televisi. Hasil dari penelitian ini menunjukkan bahwa variabel independen empati pengaruh yang signifikan terhadap citra merek.

3. Ira Setiawati, dalam penelitiannya Pengaruh Strategi Pemasaran Online Terhadap Peningkatan Laba Umkm. Hasil penelitiannya menunjukkan bahwa Strategi pemasaran online berpengaruh positif terhadap Laba Usaha Mikro Kecil dan Menengah (UMKM) di Jawa Tengah.

4. Nadrotul Ulyah. Dengan judul penelitiannya Analisis Strategi Pemasaran Untuk Meningkatkan Penjualan Pada Pt. Bhirawa Steel, penelitian yang dilakukan Nadrotul Ulyah memaparkan hasil bahwa dalam sebuah strategi pemasaran hendaknya perushaan harus melakukan inovasi dan pengembangan pemasaran berkala untuk meningkatkan tingkat penjualan produk 


\section{KERANGKA KONSEPTUAL}

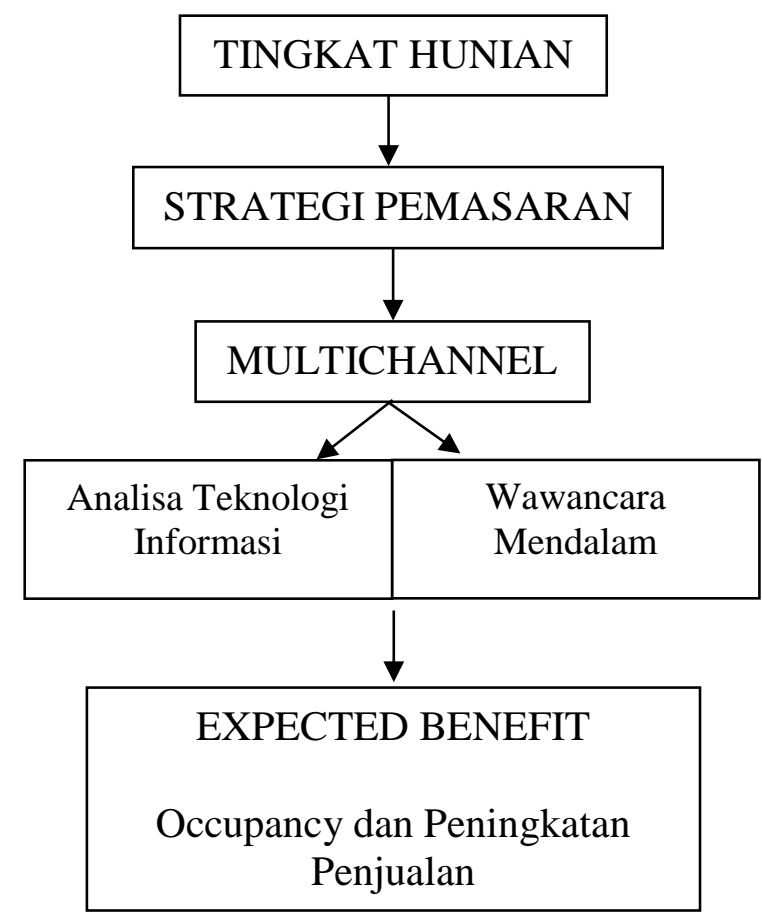

\section{METODELOGI PENELITIAN}

\section{Lokasi Penelitian}

Avilla Bali didirikan oleh Herry Antolis dan Jemmy Sugihartono, lulusan jurusan Arsitektur di Surabaya, dan Henry Setiono lulusan dari Jurusan Manajemen Bisnis. Bersamasama mereka memutuskan untuk menciptakan perusahaan perhotelan dengan visi untuk menjadi Juara Lokal Bali dalam bisnis perhotelan. Avilla Bali adalah perusahaan perhotelan yang mengelola berbagai hotel, villa, dan restoran di seluruh Bali. Semuanya dimulai dengan pembangunan dan pendirian Le Jardin Boutique Villas di Seminyak pada tahun 2007, kemudian dilanjutkan dengan pembukaan Kokonut Suites pada tahun 2008. Setelah itu, Avilla Bali melebarkan sayapnya ke industri restoran dengan membuka Bale Udang Mang Engking Kuta pada tahun 2009. Tahun 2013 menandai Alindra villa dan Berry Amour Villas sebagai bagian dari Avilla bali, diikuti oleh Bale Udang Mang Engking Ubud dan Berry Biz Hotel pada tahun 2014 dan Berry Glee Hotel pada tahun 2016. Anggota terbaru Avilla Bali adalah Cabina dan Livingstone yang bergabung dengan Avilla Bali pada 2018. Avilla dibagi lagi menjadi beberapa kelompok group yang tersebar di Kabupatem Badung, Salah Satunya adalah group Berry yang berpusat di Jl. Sunset Road No. 99 Badung Bali. 


\section{Desain Penelitian}

Pemasaran jasa khususnya kamar beralih digital booking melalui perantara E-commerce sebagai alat pendukung, sistem ini mampu memberi informasi lengkap kondisi sebuah lokasi penginapan dan fasilitas yang disediakan. Penelitian menggunakan metode deskriptif kualitatif, pemilihan metode ini diharapkan mampu memperoleh informasi yang realistis sesuai dengan fenomena yang terjadi dan dialami langsung oleh informan. Dengan melakukan wawancara sistematik diharapkan data yang diperoleh dapat menjawab permasalahan. Burhan Bungin (2013) wawancara sistematik adalah wawancara yang dilakukan dengan mempersiapkan pedoman dan alur wawancara untuk mendapatkan data sesuai dengan penelitian.

\section{Informan Penelitian}

Penelitian ini mengkaji tentang startegi E-commerce dalam optimalisasi tingkat hunian kamar, maka teknik yang digunakan adalah purposive sampling yaitu teknik pengambilan sample dengan pertimbangan tertentu atau disebut juga dengan penarikan sample, (Sugiyono, 2014) maka peneliti memustuskan mewawancarai informan yang dianggap memiliki pengalaman dan pengetahuan tentang sistem pemasaran yang digunakan. Informan terdiri dari 4 (empat) orang ahli.

\section{Definisi Operasional}

Strategi optimalisasi E-commerce dalam optimalisasi tingkat hunian adalah dari definisi operasional dimana E-commerce adalah Sistem yang diciptakan sebagai alat baru pendukung dalam pemasaran produk atau jasa melalui perantara internet sebagai media publikasinya. Pemasaran modern produk jasa dengan metode ini menggunakan platform web, startup mampu menyediakan informasi besbasis teknologi informasi dengan media pendukung visualisasi video dan animasi gambar dan dapat diakses yang tidak terbatas tempat dan waktu.

\section{Teknik Pengumpulan Data}

Dalam penelitian ini peneliti mengumpulkan data melalui wawancara secara langsung dengan pihak yang mempunyai pengetahuan yang berhubungan dengan penelitian. Menurut Sugiyono (2013) Metode wawancara merupakan teknik pengumpulan data apabila peneliti ingin melakukan studi pendahuluan untuk menemukan permasalahan yang harus diteliti, dan juga mengetahui hal-hal dari responden yang lebih mendalam dan jumlah respondennya. 


\section{Teknik Analisis Data}

Teknik reduksi adalah teknik yang digunakan dalam penelitian ini peneliti, data yang di reduksi adalah data informan yang dilakukan mulai dari awal penelitian. Menurut Sugiyono (2013) tahap ini peneliti melakukan pemilihan, pemusatan perhatian pada penyederhanaan dari hasil wawancara, abstraksi dan transformasi data kasar yang diperoleh dari informan, kemudian memilih data yang relevan dari beberapa data yang sebelumnya diperoleh.

\section{Verifikasi Keabsahan Hasil Analisis}

Keabsahan data dalam penelitian ini menggunakan metode triangulasi, untuk memperoleh informasi data dari subjek atau informan peneliti melakukan wawancara berdasarkan tempat dan waktu yang berbeda, tringalasi dilakukan untuk mencocokan sumber data dari infoman satu dengan informan lain. Menurut Sugiyono (2013) Triangulasi berarti peneliti melakukan menggunakan pengumpulan data yang berbeda - beda salah satu cara untuk medapatkan data adalah dengan melakukan wawancara dalam waktu dan informan yang berbeda.

\section{TEMUAN PENELITIAN DAN PEMBAHASAN}

Berdasarkan data yang diperoleh peneliti Avilla menggunakan strategi bauran pemasaran yaitu dengan menggunakan pemasaran offline dan online. Pada segment offline management bekerjasama dengan penyedia jasa perjalan wisata atau travel agent offline, pada segment online pemasaran menggunakan media sosial, web dan startup E-commerce. Strategi pemasaran disusun oleh manager marketing yang dikordinasikan bersama team $E$-commerce kemudian direalisasikan oleh IT sebagai tim teknis penyedia kebutuhan software maupun hardware. Implementasi pemasaran digitital atu E-commerce menggunakan 2 komponen sistem utama, yang pertama adalah sistem internal hotel VHP visual hotel program dan sistem channel manager Rategain. Sistem internal hotel adalah sistem yang digunakan dalam menyusun data harga kontrak pasar atau yang disebut kontrak rate dalam istilah sistem hotel. Kontrak rate disusun berdasarkan segment pasar yang akan dituju online dan offline, Rategain adalah sebuah channel manager, sistem Rategain berbasis cloud sebagai inovasi teknologi terbaru dalam kecerdasan tingkat tinngi, pengoptimalan harga, distribusi elektronik dan keterlibatan merek. Sistem cloud mepunyai kelebihan dapat diakses menggunakan internet tanpa ketebatasan tempat dan waktu. Channel manager Rategain mendistribusikan kontrak rate dari sistem internal ke online travel agent (OTA). 
Adapun perbedaan kontrak offline $10 \%$ lebih rendah dari online, data yang diperoleh dari informan kontrak pada segment offline memiliki sifat tetap yang tidak dipengaruhi dinamika kondisi pasar low season dan high season. Sedangkan pada online memiliki sifat dinamis dimana kontrak tidak terikat tetap, dari data yang dipeloreh rata - rata $40 \%$ tingkat hunian kamar $60 \%$ dari OTA ini membuktikan tingkat peluang implementasi pemasaran dengan $E$ commerce. Namun permasalahan yang terjadi dalam pengggunaan E-commerce yaitu mengalami slow respon pada channel manager mengalami dealy pendistribusian data yang menyebabkan over booking. kondisi ini disebabkan 2 sumber yang pertama adalah human error, kedua terjadi karena miss komunikasi antara sistem internal dan channel manager. Dalam penelitian ini penulis berharap dengan pengembangan inovasi teknologi, segment offline dapat dikembangkan ke online serta meningkatkan strategi pemasaran yang lebih optimal.

\section{Implementasi Pemasaran}

Flowchart pada gambar 1 dapat dijelaskan alur pemasaran yang digunakan. Team marketing, team E-commerce dan team IT merupakan satu kesatuan yang dibangun untuk menganalisa, mengusun startegi pemasaran. Data akan diinput kemudian diproses oleh internal sistem didistribusikan ke sistem global multi channel marketing meliputi OTA online travel marketing, website dan media sosial. Dengan bantuan alat internal sistem pemasaran mengunakan push rate teknik ini mampu mendistribusikan data kontrak pemasaran kesemua channel yang sudah bekerjasama kecuali offline travel agent karena offline travel agent memiliki kontrak terpisah dengan kontrak OTA, Jika dilihat dari gambar 1 Sistem pemasaran yang diimplementasikan tidak sepenuhnya terintegrasi secara online, $40 \%$ dari $100 \%$ hunian masih merangkul offline. Dalam menghadapi presaingan digital, peningkatan strategi pemasaran harus dilakukan dengan mengurangi segment offline ke online. Menurut Herry Achmad Buchory dan Djaslim Saladin (2010) menyatakan bahwa Perusahaan perlu membuat dan menyusun strategi - strategi yang cocok, relevan dan memadai sesuai dengan usahanya atau dengan kata lain perusahaan dituntut untuk dapat menerapkan manajemen strategik dengan baik. Untuk mencapai tingkat hunian yang diharapkan management harus mampu melihat peluang pontensi pasar pontensial untuk mendapatkan nilai revenue yang optimal. 


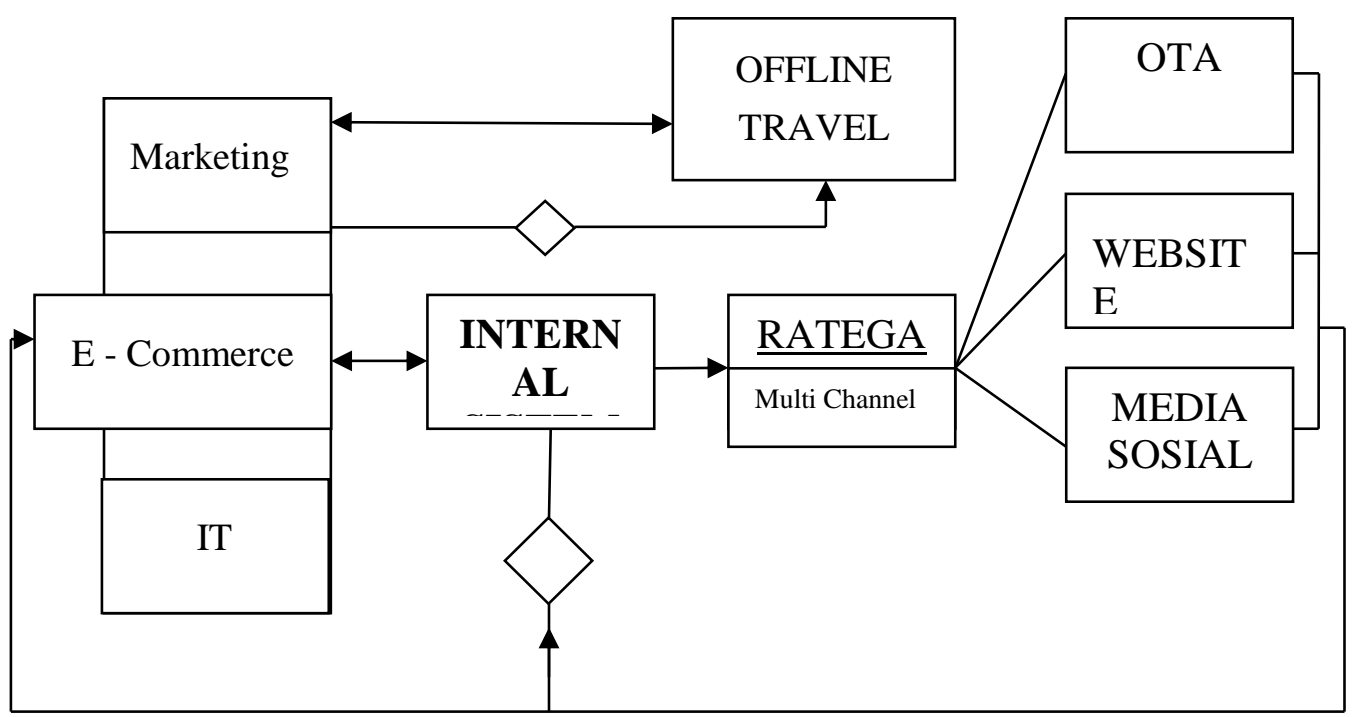

Gambar 1. Flowchart pemasaran

\section{MATRIK SWOT}

Matrik SWOT di atas digunakan untuk menemukan kekuatan, kelemahan, peluang dan ancaman yang dimiliki management. Pada Gambar flowchart 1 digunakan sebagai analisis penulis untuk melihat gambaran alur distribusi pemasaran. Sehingga faktor - faktor yang menjadi pontensi dalam menyusun strategi dapat dimaksimalkan dalam penyermpurnaan strategi melalui pengembangan inovasi. 


\begin{tabular}{|c|c|}
\hline STRENGTH & WEAKNESSES \\
\hline $\begin{array}{l}\text { 1. Konsep unit city hotel } \\
\text { dan romantik. } \\
\text { 2. Sistem teknologi } \\
\text { mendukung. } \\
\text { 3. Pemasaran multichannel } \\
\text { marketing sistem. } \\
\text { 4. Sistem hotel terintegrasi } \\
\text { dan dapat diaccess tanpa } \\
\text { batasan waktu. } \\
\text { 5. Database folio Kastemer. }\end{array}$ & $\begin{array}{l}\text { 1. Troubleshoot sistem } \\
\text { problem lambat } \\
\text { 2. Pengembangan } \\
\text { sistem teknologi } \\
\text { belum maksimal. } \\
\text { 3. Masih mengunakan } \\
\text { pemasaran offline. } \\
\text { 4. Management saat ini } \\
\text { menyerahkan } \\
\text { strategi pemasaran } \\
\text { ke unit masing - } \\
\text { masing dengan } \\
\text { kontrol Direktur } \\
\text { Operation claster. } \\
\text { 5. Mobile sistem masih } \\
\text { belum digunakan. }\end{array}$ \\
\hline OPPORTUNITIES & THREATS \\
\hline $\begin{array}{l}\text { 1. Pengembangan inovasi } \\
\text { web dan startup mobile. } \\
\text { 2. Pengembangan database } \\
\text { offline. } \\
\text { 3. Mayoritas } \\
\text { booking kamar melalui } \\
\text { OTA. }\end{array}$ & $\begin{array}{l}\text { 1. Price rate pesaing } \\
\text { pada OTA. } \\
\text { 2. Startup mobile } \\
\text { sistem. } \\
\text { 3. Jumlah pesaing. }\end{array}$ \\
\hline
\end{tabular}

\section{Pengembangan Sistem}

Untuk mengurangi biaya pemasaran offline sistem internal dapat dikembangkan pada startup mobile dengan menbangun fitur Reservation sistem, Mobile Check in, Bill Information sistem, Keycard mobile sistem, Payment by mobile. Web pop up ditambahkan pada unit yang belum mengunakan fitur рор ир. Pendistribusian informasi dapat dilakukan dengan boardcast email ke kastemer offline yang sebelumnya menginap, data ini diperoleh dari sistem internal 
melalui team marketing, pengembangan ini bertujuan mempertahakan posisi top production pada segement pasar online. Adapun rancangan pengembangan dituangkan pada gambar 2.

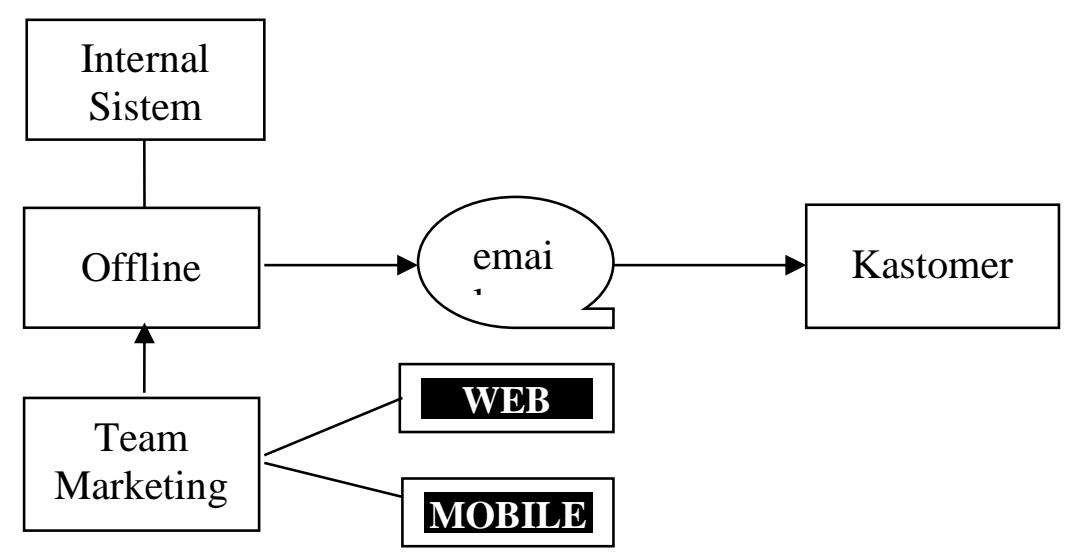

Gambar 2. Pengembangan sistem internal.

\section{PENUTUP}

Berdasarkan penelitian yang dilakukan penulis di Avilla disimpulkan bahwa, Management mengunakan strategi marketing mix dalam pemasaran kamar yaitu dengan memadukan kemajuan teknologi informasi dengan pemasaran konvensioanal atau yang disebut dengan offline travel agent dan online travel agent (OTA). Faktor Keberhasilan pemasaran dengan E-commerce dipengaruhi oleh banyak booking yang dapat dicatat oleh OTA pada masing - masing channel, untuk mempertahankan dan memberi sugest optimal top productin dalam setiap page OTA management mengunakan strategi persaingan harga. Management menggukan baruan pemasaran atau market mix dalam proses pemasaran dengan menggunakan channel manager sebagi media distribusi data ke masing - masing channel pemasaran. Channel manager ini mampu memberikan efektifitas waktu, jangkauan pemasaran yang luas, tidak terikat oleh waktu dan dapat diakses 24 jam selama koneksi internet tersidia. Pemasaran $E$ commerce management menggunakan Channel manager Rategain yang mampu mendritribusikan data pemasaran dengan tepat ke masing - masing channel OTA yang bekerjasama dengan unit, namun kedala yang dialami untuk saat ini pada channel manager rategain sewaktu mengalami slow respon untuk menditribusikan data.

Proses pemasaran masih menggunakan offline sebanyak $40 \%$ dari rata - rata booking disetiap unit, diharapkan budgeting sektor offline dapat dialokasikan untuk pengembangan sistem internal dengan pemutahiran web yang terintergrasi mobile sistem, dengan perubahan ini diharapkan dapat mengurangi pemasaran yang bersifat konvensional yang dinilai 
memerlukan biaya yang tinggi. Untuk mempertahankan posisi top production pada masing masing channel OTA maupun pada mesin pecari, pengembangan dan peningkatan tingkat hunian kamar management dapat melakukan penyusunan mobile sistem dapat memberikan kemudahan transaksi dengan fitur yang dapat dikembangkan mendukung misi Smart Traveler pada sisi sebagai berikut:

1. Reservation sistem.

2. Mobile Check in.

3. Bill Information sistem.

4. Keycard mobile sistem.

5. Payment by mobile sistem. 


\section{DAFTAR PUSTAKA}

Achmad, B.H., and Djaslim Salidin. (2010). Manajemen Pemasaran. Bandung: Linda Karya. Adnyana, R., and Darma, G.S. (2015). Strategi Marketing Mix, Yield Management, Customer Satisfaction and Occupancy Rate, Jurnal Manajemen \& Bisnis, 12 (1): 92-115.

Ariesto, A. S. (2002). Analisis dan desain berorientasi objek. Yogyakarta.

Bungin, H. M. B. (2013). Metodologi Penelitian Sosial dan Ekonomi.

Badan Pusat Statistic Provinsi Bali. (2017). Berita Resmi Statistic Bulan November 2017 Provinsi Bali, No. 78/12/51/Th. XI.

Darma, G.S. (2018). Seuntai Pesan, Menjawab Zaman. Indonesia: Pustaka Larasan Press.

Darma, G.S. (2019). Kacamata Media, Kesuksesan Bersyarat. Indonesia: Pustaka Larasan Press.

Darma, G.S., Apollo, A., Rusmanda, G., and Umar, Y. (2019). Digital Education 4.0. Indonesia: Cakra Media Utama Press.

Dewi, C.R., and Darma, G.S. (2014). Website Usability, Satisfaction, Loyalty, Security Perception, Trust, and Word of Mouth in e-Commerce Business, Jurnal Manajemen \& Bisnis, 11 (2): 1-30.

Djajadi, M. (2013). Analisis Pengaruh Kualitas Pelayanan dan Citra Perusahaan Terhadap Loyalitas Mahasiswa Dengan Kepuasan Mahasiswa Sebagai Variabel Intervening, Jurnal Program Pascasarjana Magister Manajemen Universitas Dian Nuswantoro Semarang.

Ferdiana, A.M.K., and Darma, G.S. (2019). Understanding Fintech Through Go-Pay, International Journal of Innovative Science and Research Technology, 4 (2): 257-260.

Furnham, A. (2015). The Myers-Briggs Type Indicator (MBTI) and Promotion at Work. Research Department of Clinical, Scientific Research Publishing, 6:1510-1515.

Handika, M.R., Maradona, A.F., and Darma, G.S. (2018). Strategi Pemasaran Bisnis Kuliner Menggunakan Influencer Melalui Media Sosial, Jurnal Manajemen \& Bisnis, 15 (2): 188-199.

http://bali.tribunnews.com/2017/04/20/jumlah-hotel-di-bali-naik-jadi-2079disparda-dan-phriusulkan-moratorium?page=all.

http://avillabali.com.

Kanten, I.K., and Darma, G.S. (2017). Consumer Behaviour, Marketing Strategy, Customer Satisfaction, and Business Performance, Jurnal Manajemen \& Bisnis, 14 (2): 143-165. 
Kotler, P., and Kevin Lane Keller. (2009). Manajement Pemasaran, Edisi 13 Jilid 2. Jakarta: Indeks.

Kotler, P., dan Kevin Lane Keller. (2012). Marketing Management.

Kasali, R. (2017). Disruption. Gramedia Pustaka Utama.

Kasali, R. (2017). Tomorrow is today. Gramedia Pustaka Utama.

Kusnadi, D.S., and Darma, G.S. (2018). Menakar Implementasi Green Marketing Pada Usaha Kecil Menengah, Jurnal Manajemen \& Bisnis, 15 (1): 1-18.

Maharani, I.G.A.P.D., and Darma, G.S. (2018). Consumer Purchasing Behavior Analysis on Impulse Buying, Jurnal Manajemen \& Bisnis, 15 (3): 16-37.

Mendez, M. (2015). Sales Promotion and Brand Loyalty: Some New Insights, Internasional Journal of Education and Social Science, 2 (1).

Pranata, I.M.A., and Darma, G.S. (2014). Strategi Penerapan E-Commerce Dalam Meningkatkan Keunggulan Bersaing, Jurnal Manajemen \& Bisnis, 11 (1): 69-81.

Piarna, R. (2014). Pengaruh Sumber Informasi dan Kualitas Website terhadap Kepercayaan Pelanggan dalam Menentukan Keputusan Bertransaksi pada E-commerce, Jurnal Pascasarjana Fakultas Ekonomi \& Bisnis Universitas Brawijaya. ISSN: 1693-5241.

Rehman, S.U. (2011). Integrated Marketing Communication and Promotion, International Refereed Research Journal, E-ISSN 2229-4686. ISSN 2231-4172.

Septiansyah, V. (2017). Perlindungan Hukum Terhadap Konsumen Dalam Perdagangan Barang Dan Bisnis Investasi Melalui Transaksi Elektronik (E-Commerce), Jurnal Mahasiswa S2 Hukum Untan, 4 (4).

Setiawati, I. (2017). Pengaruh Strategi Pemasaran Online Terhadap Peningkatan Laba UMKM, Jurnal Pasca Sarjana STIE Dharmaputra Semarang. 343-347.

Strauss, J., and Raymond Frost. (2013). E-Marketing.

Sawyer, W. (2007). Information Technology.

Sugiyono. (2013). Metode Penelitian Kuantitatif Kualitatif dan R\&D. Bandung: Alfabeta.

Salinan Undang - Undang Republik Indonesia. (2009). Tentang Kepariwisataan. Nomor 10 tahun 2009.

Salinan Peraturan Menteri Pariwisata Dan Ekonomi Kreatif Republik Indonesia. (2013). Tentang Standar Usaha Hotel. Nomor Pm.53/Hm.001/Mpek/2013.

Ulyah, N. (2016). Analisis Strategi Pemasaran Untuk Meningkatkan Penjualan Pada Pt. Bhirawa Steel, Artikel Ilmiah Sekolah Tinggi Ilmu Ekonomi Perbanas Surabaya: 1-18.

Wong, J. (2010). Internet Marketing for Beginners. Jakarta: Elex Media Komputindo. 
Yuli, A. (2011). City Branding Sebagai Strategi Pengembangan Pariwisata Ditinjau Dari Aspek Hukum Merek (Studi Kasus City Branding Daerah Istimewa Yogyakarta Sebagai Daerah Tujuan Wisata Unggulan di Indonesia), Jurnal Ilmu Ilmiah Hukum QISTI, 5 (1). Yuniar. (2012). Pengaruh Empati, Persuasi, Dampak, Komunikasi Terhadap Citra Merek Dikalangan Mahasiswa Program Pasca Sarjana Magister Manajemen Universitas Syiah Kuala Banda Aceh, Jurnal Manajemen Pascasarjana Universitas Syiah Kuala, 2 (1): 102-115. ISSN: 2302-0199. 